\title{
Article \\ Optimization of Mechanical and Setting Properties in Acrylic Bone Cements Added with Graphene Oxide
}

\author{
Lina Marcela Ruiz Rojas ${ }^{1}$, Mayra Eliana Valencia Zapata ${ }^{1}\left(\right.$, Marisol Gordillo Suarez ${ }^{2}$, Rigoberto Advincula ${ }^{3,4}$, \\ Carlos David Grande-Tovar ${ }^{5, *(1)}$ and José Herminsul Mina Hernández ${ }^{1}$ (D) \\ 1 Grupo de Materiales Compuestos, Escuela de Ingeniería de Materiales, Universidad del Valle, \\ Calle 13 \# 100-00, Cali 76001, Colombia; ruiz.lina@correounivalle.edu.co (L.M.R.R.); \\ valencia.mayra@correounivalle.edu.co (M.E.V.Z.); jose.mina@correounivalle.edu.co (J.H.M.H.) \\ 2 Grupo de Investigación en Modelación y Simulación, Facultad de Ciencias Básicas, Universidad Autónoma \\ de Occidente, Calle 25 \#115-85 Km 2, Cali 76001, Colombia; mgordillo@uao.edu.co \\ 3 Department of Chemical and Biomolecular Engineering, University of Tennessee, Knoxville, TN 37996, USA; \\ rca41@case.edu \\ 4 Center for Nanophase Materials Sciences (CNMS), Oak Ridge National Laboratory, \\ Oak Ridge, TN 37830, USA \\ 5 Grupo de Investigación de Fotoquímica y Fotobiología, Universidad del Atlántico, Carrera 30 Número 8-49, \\ Puerto Colombia 081008, Colombia \\ * Correspondence: carlosgrande@mail.uniatlantico.edu.co; Tel.: +57-5-3599484
}

check for updates

Citation: Ruiz Rojas, L.M.; Valencia Zapata, M.E.; Gordillo Suarez, M.; Advincula, R.; Grande-Tovar, C.D.; Mina Hernández, J.H. Optimization of Mechanical and Setting Properties in Acrylic Bone Cements Added with Graphene Oxide. Appl. Sci. 2021, 11, 5185. https://doi.org/10.3390/ app11115185

Academic Editor: Ioana Chiulan

Received: 28 April 2021

Accepted: 31 May 2021

Published: 3 June 2021

Publisher's Note: MDPI stays neutral with regard to jurisdictional claims in published maps and institutional affiliations.

Copyright: (c) 2021 by the authors. Licensee MDPI, Basel, Switzerland. This article is an open access article distributed under the terms and conditions of the Creative Commons Attribution (CC BY) license (https:/ / creativecommons.org/licenses/by/ $4.0 /)$.

\begin{abstract}
The extended use of acrylic bone cements (ABC) in orthopedics presents some disadvantages related to the generation of high temperatures during methyl methacrylate polymerization, thermal tissue necrosis, and low mechanical properties. Both weaknesses cause an increase in costs for the health system and a decrease in the patient's quality of life due to the prosthesis's loosening. Materials such as graphene oxide (GO) have a reinforcing effect on $A B C$ 's mechanical and setting properties. This article shows for the first time the interactions present between the factors sonication time and GO percentage in the liquid phase, together with the percentage of benzoyl peroxide (BPO) in the solid phase, on the mechanical and setting properties established for cements in the ISO 5833-02 standard. Optimization of the factors using a completely randomized experimental design with a factorial structure resulted in selecting nine combinations that presented an increase in compression, flexion, and the setting time and decreased the maximum temperature reached during the polymerization. All of these characteristics are desirable for improving the clinical performance of cement. Those containing $0.3 \mathrm{wt}$. $\%$ of GO were highlighted from the selected formulations because all the possible combinations of the studied factors generate desirable properties for the ABC.
\end{abstract}

Keywords: acrylic bone cement; benzoyl peroxide; completely randomized factorial design; graphene oxide; mechanical properties; PMMA; setting properties; sonication

\section{Introduction}

Acrylic bone cements (ABC) are biomaterials used since 1960 in orthopedics, and their applications extend from arthroplasty procedures [1] to neurosurgery [2], vertebroplasty, and kyphoplasty [3-5]. Arthroplasty procedures generally use ABCs with impressive results [6]. The cement mantle's prominent roles are to stabilize the implant and transfer body weight and service loads from the prosthesis to the bone $[1,7,8]$. Successful arthroplasty is related to the implants; therefore, the cement's good mechanical properties must be guaranteed [7].

$\mathrm{ABC}$ are commercialized in two components, a solid phase containing the polymer (which is usually polymethylmethacrylate, PMMA, or a derived copolymer), benzoyl peroxide (BPO), as the polymerization reaction initiator [9-12], and a radiopacifier agent such as barium sulfate $\left(\mathrm{BaSO}_{4}\right)$ or zirconium dioxide $\left(\mathrm{ZrO}_{2}\right)$. The liquid phase is composed of a monomer (generally methyl methacrylate, MMA), N,N-Dimethyl- $p$-Toluidine (DMPT) 
as an activator for the formation of radicals $[7,11]$, and hydroquinone as a stabilizer to room temperature $[1,5]$.

The mixture of BPO and DMPT produces benzoyl radicals, starting PMMA polymerization $[7,11]$. These benzoyl radicals join with the monomer and form active centers, which combine with multiple molecules to create PMMA chains [13] (Figure 1). The polymerization reaction's exothermic character may play a role in thermal necrosis of the periprosthetic tissue [6,8], inducing the implant deterioration [1].

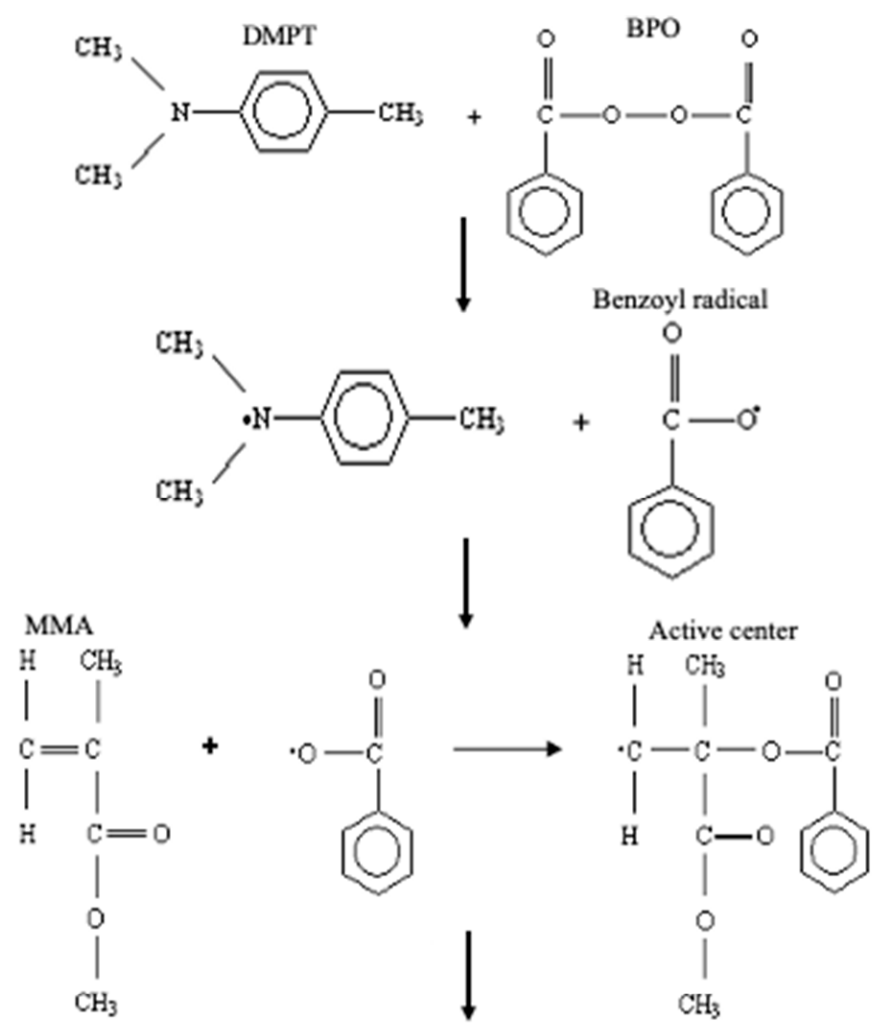<smiles>COC(=O)C(C)(CC(C)(C)C(C)(C)C(C)(C)C(C)(C)C(C)(C)C(=O)OC)C(=O)OC</smiles>

Figure 1. Schematic diagram of the free radical polymerization of MMA.

Some fillers such as hydroxyapatite (HA) [14-17], phosphate bioglasses [18,19], silicate and borate bioglasses [20,21], tricalcium phosphates [22,23], Sepia Officinalis cuttlebone [24], and biodegradable polymers such as cellulose, chitosan, polydioxanone [25], polylactic acid (PLA), $\beta$-polyhydroxy butyrate (PHB), and thermoplastic starch (TPS) have been added to the solid phase of the cement for improving different properties; however, due to the inorganic nature of some of them and the biodegradable behavior of others, losses in their mechanical properties have been generated [26].

Graphene oxide (GO) is a two-dimensional material, a graphene sheet with oxygen groups over its surface [27]. Usually, GO attracts significant attention in biomedical applica- 
tions due to its high mechanical performance, biocompatibility, biodegradation [26,28-31], and excellent antibacterial properties [32,33].

Several types of research have demonstrated that GO content in ABCs generates a reinforcement on the mechanical properties' flexion [34,35], compression, fracture toughness [8], and fatigue performance [3]. Reduction in the maximum temperature reached during polymerization $\left(T_{\max }\right)$, increase in the setting time $\left(t_{\text {set }}\right)$ [3,36-38], and additionally, improvements in bioactivity [38-40] and antibacterial properties [37,41]. Despite these improvements, it has also been reported that GO in ABCs can inhibit the polymerization reaction, which can be counteracted by increasing the radical species. However, since the $\mathrm{BPO}$ content influences the polymerization exotherm $\left(T_{\max }\right)$ [1], it is necessary to optimize its content.

The effect of GO's sonication time has been studied in materials different from ABCs [42-44], and it has been found that this parameter is related to two key characteristics of GO: the lateral size and the thickness of the sheets $[45,46]$. Increasing the sonication time decreases the thickness and particle size, as previously reported [47]. However, excessive sonication decreases hydrophilicity and functional groups in GO sheets [48] with a simultaneous increase in GO structure defects [49,50].

Although there are several types of research where the GO content alone is studied, there are no studies on the interactive effects of the size and content of GO and the BPO content. This article shows for the first time the interactions present between the factors sonication time and GO percentage in the liquid phase, together with the percentage of benzoyl peroxide (BPO) in the solid phase, on the mechanical and setting properties established for cements in the ISO 5833-02 standard [51]. Optimization of the factors using a completely randomized experimental design with factorial structure resulted in selecting nine formulations that presented an increase in compression, flexion, and the setting time and decreased the maximum temperature reached during the polymerization. Some of these combinations have not yet been studied, which broadens the possibilities for new formulations with desirable characteristics to improve $\mathrm{ABCs}$ ' clinical performance, which could be used in orthopedics.

\section{Materials and Methods}

\subsection{Materials}

The solid phase was composed of PMMA beads (Veracril ${ }^{\circledR}$ New Stetic SA, Medellin, Colombia), BPO, and $\mathrm{BaSO}_{4}$ (Alpha Aesar, Tewksbury, MA, USA). The liquid phase was composed of MMA (Merck, Burlington, MA, USA), 2-(diethylamino) ethyl acrylate (DEAEA), 2-(diethylamino) ethyl methacrylate (DEAEM) (Sigma Aldrich, Palo Alto, CA, USA), DMPT (Merck, Burlington, MA, USA), and graphene oxide synthesized in the laboratory by a modification of the Hummers method [37,38].

\subsection{Experimental Design}

A completely randomized experimental design with a factorial structure was applied to analyze the information obtained in this study statistically. The study factors considered and their levels are shown in Table 1. Each level selected for the factors was based on a review of the values used in the formulations of cements containing GO. A total of 60 tests were conducted (20 treatments with 3 repetitions) for each of the 6 response variables. The tests were performed at random under identical conditions. The analysis of variance (ANOVA), post-ANOVA tests (Tukey test), and graphs of the data obtained was carried out in the statistical package MINITAB version 19 (Minitab, LLC, State College, PA, USA). Simultaneously evaluated was the interaction significance and the factor effects over the response variables. 
Table 1. Completely randomized experimental design with factorial structure applied in this study.

\begin{tabular}{cc}
\hline Factors & Levels \\
\hline Sonication time $(\mathrm{h})$ & 1 and 5 \\
BPO/Solid ratio (wt.\%) & 2 and 2.5 \\
GO/Liquid ratio (wt. $\%)$ & $0,0.1,0.2,0.3$, and 0.5 \\
\hline \multicolumn{2}{c}{$\begin{array}{c}\text { Response Variables } \\
\text { compressive strength, compressive modulus, } \\
\text { bending strength, and bending modulus }\end{array}$} \\
\hline
\end{tabular}

Simultaneously, the importance of the interaction and each factor's primary effects on the response variable was assessed [52,53]. Equation (1), expressing the completely randomized design model with a factorial structure, is given by

$$
Y_{i j k l}=\mu+Z_{i}+\beta_{j}+\alpha_{k}+(Z \beta)_{i j}+(Z \alpha)_{i k}+(\beta \alpha)_{j k}+(Z \beta \alpha)_{i j k}+\varepsilon_{i j k l}
$$

where $Y$ is the response variable, $\mu$ is the general mean, $Z$ is the effect due to sonication time, $\beta$ is the effect due to $\mathrm{BPO} /$ solid ratio, and $\alpha$ is the effect due to GO/liquid ratio. $(Z \beta)$, $(Z \alpha)$, and $(\beta \alpha)$ are the interaction effects, and $\varepsilon$ is the experimental error.

A completely randomized experimental design with a structure factorial has several assumptions that need to be fulfilled, such as (1) normality, (2) homoscedasticity, and (3) independence.

\subsection{Preparation of $G O$}

GO was obtained by the Hummers method modified as reported by Valencia et al. [37]. Briefly, $3 \mathrm{~g}$ of graphite were oxidized with $\mathrm{H}_{2} \mathrm{SO}_{4}$ and $\mathrm{KMnO}_{4}$ for 4 days, purified by dialysis, and dried by lyophilization. The characterizations made to GO are reported in previous studies $[37,38]$. The lateral size of GO dispersed for $1 \mathrm{~h}$ measured by dynamic light scattering (DLS) was $400 \mathrm{~nm}$, while the one spread for $5 \mathrm{~h}$ was $367 \mathrm{~nm}$. The GO thickness determined by Atomic force microscopy (AFM) was $<30 \mathrm{~nm}$, the level of oxidation by X-ray photoelectron spectroscopy (XPS) was $67.84 \%$, and the interlaminar distance determined by X-ray diffraction (XRD) was $7.953 \AA$.

\subsection{Preparation of $A B C s$}

The solid phase (SP) of the cement consisted of $10 \mathrm{wt} . \% \mathrm{BaSO}_{4}$, the $\mathrm{BPO}$ content was taken from the experimental design shown in Table S1 (Supporting Information), and the amount of PMMA was adjusted to complete $100 \%$ of the SP. The SP components were mixed manually.

In the liquid phase (LP), the percentage of DMPT and comonomers were constant for all formulations at $2.5 \mathrm{wt} . \%$ and $2.0 \mathrm{wt} . \%$, respectively. The total comonomer consisted of a 50:50 mixture of the alkaline comonomers DEAEA and DEAEM. The GO content was taken from the experimental design shown in Table S1 (Supporting Information), and the amount of MMA was adjusted to complete $100 \%$ of the LP. LP was obtained by mixing the components and subsequent sonication in an ultrasonic bath (Branson, Danbury, CT, USA) at $25^{\circ} \mathrm{C}$ and $40 \mathrm{kHz}$ frequency by 1 or $5 \mathrm{~h}$ according to the treatment given in the experimental design.

$\mathrm{LP}$ was added to SP in an SP/LP ratio of $2 \mathrm{~g} / \mathrm{mL}$, and the dough was manually mixed and deposited in Teflon molds with the form required for each test (Figure 2). 


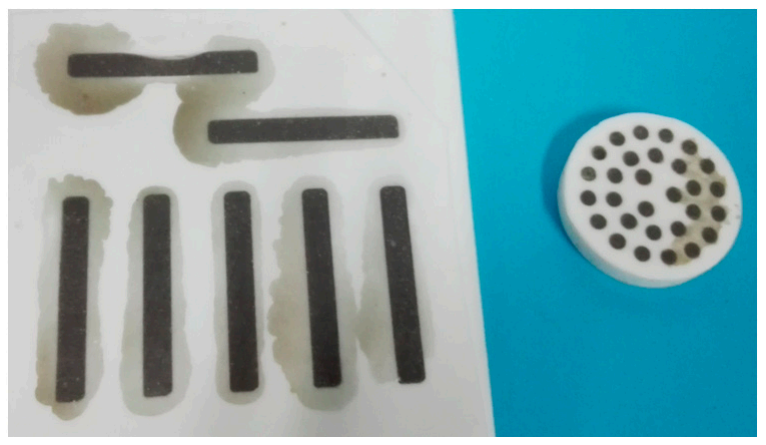

Figure 2. Molds with bending and compression specimens.

\subsection{Characterization of $A B C s$}

The cements' characterization was based on the evaluation methods proposed in the ISO 5833-02 [51] standard for ABCs.

\subsubsection{Setting Properties}

After mixing SL and LP, the dough was put in molds $68 \mathrm{~mm}$ in diameter and $20 \mathrm{~mm}$ in height, and the temperature and time were registered with a data acquisition system with a USB port containing a thermocouple for temperature sensing (Figure 3a). $T_{\max }$ was the higher temperature reached during the polymerization reaction, and the $t_{\text {set }}$ was calculated as the time where the $T_{\text {set }}$ was reached. $T_{\text {set }}$ was determined by Equation (2). The test was conducted in duplicated.

$$
T_{\text {set }}=\frac{T_{\max }+T_{a m b}}{2},
$$

where: $T_{\text {set }}$ is the setting temperature, and $T_{a m b}$ is the ambient temperature.
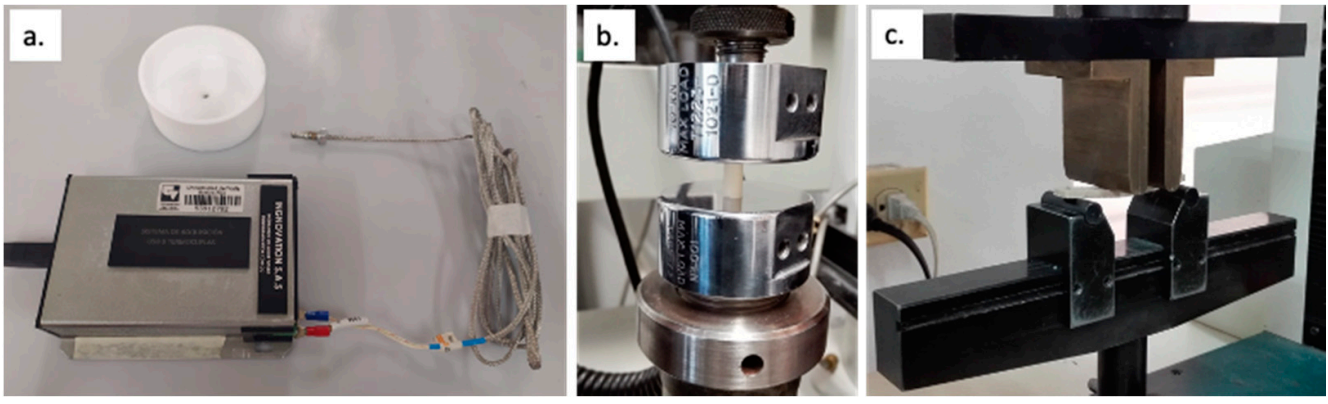

Figure 3. Equipment used for data acquisition. (a) setting test, (b) compressive properties, and (c) bending properties.

\subsubsection{Mechanical Properties}

Mechanical properties were characterized in a universal testing machine Tinius OlsenH50KS (Tinius Olsen, Redhill, United Kingdom). Compressive strength and compressive modulus were measured in cylinders with $6 \mathrm{~mm}$ in diameter and $12 \mathrm{~mm}$ in height to crosshead displacement rate of $20 \mathrm{~mm} / \mathrm{min}$ (Figure $3 \mathrm{~b}$ ). Each formulation tested six samples. A fourpoint bending test was conducted on rectangular beams of $75 \mathrm{~mm} \times 10 \mathrm{~mm} \times 3 \mathrm{~mm}$ with a $5 \mathrm{~mm} / \mathrm{min}$ crosshead displacement rate (Figure $3 \mathrm{c}$ ). Bending strength and bending modulus were calculated according to the ISO 5833-02 [51] specifications.

\section{Results and Discussion}

\subsection{Setting Properties}

For analysis of the maximum temperature and setting time variables based on the effect of sonication time, $\mathrm{BPO} / \mathrm{SP}$ ratio, and GO/LP ratio, a completely randomized design 
model with a factorial structure was proposed, which meets the assumptions of normality about error of the model, at significance levels greater than $p$-value $=0.15$.

\subsubsection{Maximum Temperature}

The analysis of variance is shown in Table S2 (support information). The $T_{\text {max }}$ delivers that all the effects of the interaction were significant at levels below 0.021 (sonication time * $\mathrm{BPO} /$ solid ratio; sonication time ${ }^{*} \mathrm{GO} /$ liquid ratio; $\mathrm{BPO} /$ solid ratio ${ }^{*} \mathrm{GO} /$ liquid ratio and sonication time ${ }^{*} \mathrm{BPO} /$ solid ratio ${ }^{*} \mathrm{GO} /$ liquid ratio). A determination coefficient of $94.64 \%$ was obtained, which is a good measure of the controlled effects' contribution (studied factors) to the total variation.

Figure 4 exhibits the interaction plot for $T_{\max }$. Increasing the sonication time and the $\mathrm{BPO} /$ solid ratio promoted the higher values of $T_{\max }$, while the higher GO percentages decrease the $T_{\max }$ reached during polymerization. $T_{\max }$ values of all the formulations studied were found between 41 and $58^{\circ} \mathrm{C}$, below the maximum value allowed by the ISO 5833-02 standard, $90^{\circ} \mathrm{C}$. In $\mathrm{ABC}$, a reduction in the $T_{\max }$ reached during polymerization is desirable since it reduces the thermal necrosis of the periprosthetic tissue $[6,12,54]$, which is related to the loosening of the prosthesis [55]. Several researchers have highlighted the influence of the BPO content on the maximum temperature [5,6,55], finding that a higher $\mathrm{BPO}$ content can increase the concentration of free radicals available during polymerization, generating an increase in the amount of energy released during the reaction $[11,56,57]$.

\section{Interaction Plot for Tmax Data Means $\left({ }^{\circ} \mathrm{C}\right)$}

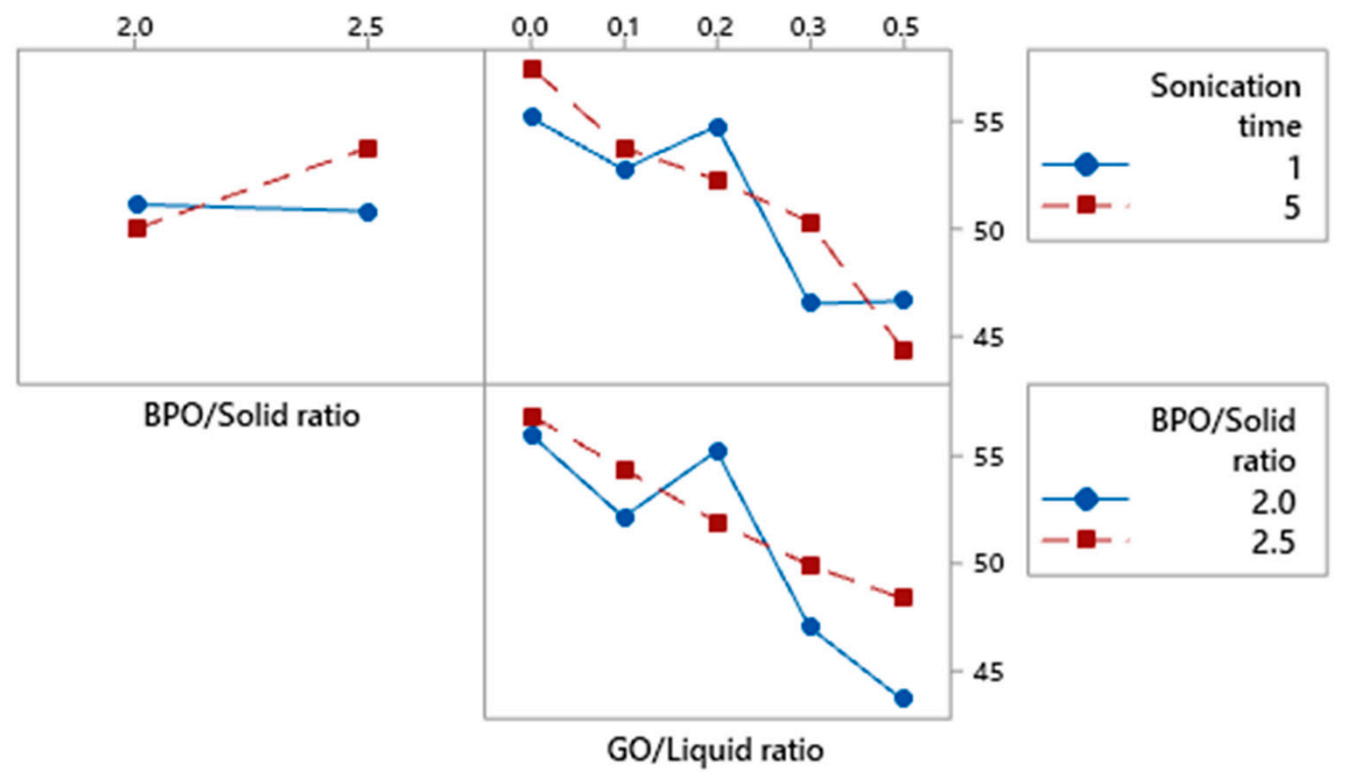

Figure 4. Interaction plot for the variable $T_{\max }$.

The sonication time is related to the degree of dispersion [50] and the thickness of the GO particle [44]. Longer exfoliation times decrease the size of GO [45,47] and possibly the heat dissipation capacity during the polymerization reaction due to the increase of the defects in the GO structure $[49,50,58]$. The decrease of $T_{\max }$ with the increase in GO content has been attributed to this component's inhibitory effect during the polymerization reaction because it acts as a sink for free radicals [34,37,38,59]. According to the results reported by Paz et al. [60], this inhibitory effect is concentration-dependent because, in their study, they showed by differential scanning calorimetry that the addition of $0.1 \mathrm{wt} . \%$ GO had no significant impact on the heat generation during the polymerization reaction of MMA. 
Tukey's multiple comparison tests shown in Table 2 indicate that group $\mathrm{G}$ formulations are the most suitable from a $T_{\max }$ point of view since they had the lowest $T_{\max }\left(<48^{\circ} \mathrm{C}\right)$. This suggests that formulations $1-2.5-0.5 ; 1-2.0-0.5 ; 5-2.0-0.3 ; 1-2.5-0.3 ; 5-2.0-0.5$ are statistically equal to a significance level of $5 \%$. All group G samples are characterized by presenting the highest GO contents studied, which indicates that this variable's effect was the most significant on $T_{\max }$. Compared to the other two studies, the lower $p$-value shown for the $\mathrm{GO} /$ liquid ratio confirms the previous statement (Table S2).

Table 2. Grouping information for $T_{\max }$ using Tukey's test and 95\% confidence.

\begin{tabular}{|c|c|c|c|c|c|c|c|c|}
\hline \multirow{2}{*}{$\begin{array}{c}\text { Sonication Time * BPO /Solid } \\
\text { Ratio * GO/Liquid Ratio }\end{array}$} & \multirow{2}{*}{$\frac{\text { Mean }\left({ }^{\circ} \mathbf{C}\right)}{58.3}$} & \multicolumn{7}{|c|}{ Grouping * } \\
\hline & & A & & & & & & \\
\hline $5-2.0-0.0$ & 56.8 & A & B & & & & & \\
\hline $1-2.0-0.2$ & 55.8 & A & B & $\mathrm{C}$ & & & & \\
\hline $1-2.5-0.0$ & 55.5 & A & B & $\mathrm{C}$ & & & & \\
\hline $5-2.5-0.1$ & 54.8 & $\mathrm{~A}$ & B & $\mathrm{C}$ & & & & \\
\hline $5-2.0-0.2$ & 54.7 & A & B & $\mathrm{C}$ & & & & \\
\hline $1-2.0-0.0$ & 54.5 & $\mathrm{~A}$ & B & C & $\mathrm{D}$ & & & \\
\hline $5-2.5-0.3$ & 54.2 & $\mathrm{~A}$ & B & $\mathrm{C}$ & & & & \\
\hline $1-2.5-0.1$ & 54.0 & $\mathrm{~A}$ & B & $\mathrm{C}$ & & & & \\
\hline $1-2.5-0.2$ & 53.8 & A & B & $\mathrm{C}$ & & & & \\
\hline $5-2.0-0.1$ & 52.8 & $\mathrm{~A}$ & B & C & $\mathrm{D}$ & & & \\
\hline $1-2.0-0.1$ & 51.5 & & B & $\mathrm{C}$ & $\mathrm{D}$ & $\mathrm{E}$ & & \\
\hline $5-2.5-0.2$ & 50.7 & & & $\mathrm{C}$ & $\mathrm{D}$ & E & & \\
\hline $5-2.5-0.5$ & 50.5 & & B & $\mathrm{C}$ & $\mathrm{D}$ & $\mathrm{E}$ & $\mathrm{F}$ & \\
\hline $1-2.0-0.3$ & 49.5 & & & $\mathrm{C}$ & $\mathrm{D}$ & $\mathrm{E}$ & $\mathrm{F}$ & \\
\hline $1-2.5-0.5$ & 47.3 & & & & $\mathrm{D}$ & $\mathrm{E}$ & $\mathrm{F}$ & G \\
\hline $1-2.0-0.5$ & 46.0 & & & & & E & $\mathrm{F}$ & G \\
\hline $5-2.0-0.3$ & 44.5 & & & & & & $\mathrm{~F}$ & G \\
\hline $1-2.5-0.3$ & 43.5 & & & & & & $\mathrm{~F}$ & G \\
\hline $5-2.0-0.5$ & 41.3 & & & & & & & G \\
\hline
\end{tabular}

\subsubsection{Setting Time}

According to Table S2 (supporting information), for the setting time variable, only the interactions sonication time ${ }^{*} \mathrm{BPO} /$ solid ratio, and sonication time ${ }^{*} \mathrm{GO} /$ liquid ratio were significant, at levels below 0.076 . A determination coefficient of $97.2 \%$ was obtained, indicating an adequate contribution of the controlled effects to the total variation.

Following Figure 5, higher values in sonication time and $\mathrm{BPO} /$ solid ratio reduced $t_{\text {set }}$, while the GO/liquid ratio increase increased $t_{\text {set }}$. ISO 5833-02 indicates that the $t_{\text {set }}$ should be between 180 and $900 \mathrm{~s}$ (3-15 $\mathrm{min}$ ), which means that all formulations studied are within the acceptable range. Setting time is one of the most representative setting parameters of the ABCs [5,55], and in orthopedics, it is expected to have a moderate value [7] because it is directly related to the time the surgeon has to mold and apply the cement during the procedure [37].

The concentration of BPO plays a vital role in the kinetic parameters of $A B C[1,55,56]$, and it is found that the decrease in $t_{\text {set }}$ with the increase of the BPO content is due to the higher amount of free radicals available to initiate the polymerization reaction faster $[5,56]$. The longer exfoliation time when generating smaller GO sizes with reduced heat dissipation capacity promotes that the cement hardening reaction occurs in less time.

According to the research of Goncalves et al. [34], the presence of the double bonds $\mathrm{C}=\mathrm{C}$ in the $\mathrm{GO}$ generates extensive electron donor-acceptor capability, so it becomes remarkably reactive toward free radicals, acting as polymerization retardation and polymerization inhibition simultaneously during the polymerization reaction of the MMA in the ABC. The same behavior has been reported by other authors who studied the radical polymerization of some typical vinyl monomers [61]. 


\section{Interaction Plot for tset Data Means (s)}

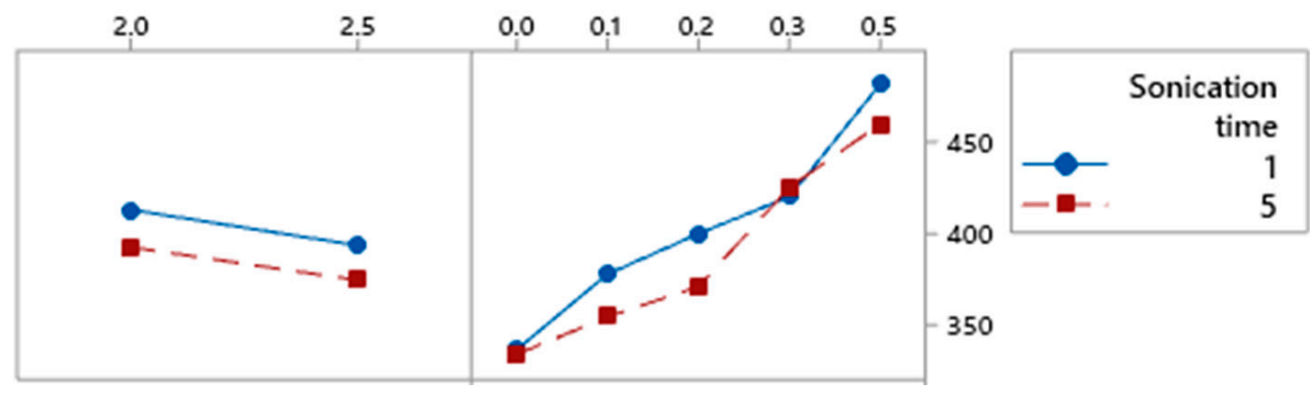

Figure 5. Interaction plot between the effect sonication time vs. BPO/solid ratio and sonication time vs. GO/liquid ratio for the variable $t_{\text {set }}$.

According to Tukey's post-ANOVA test for the $t_{\text {set }}$ variable (Table 3), although all the formulations are within the range allowed by ISO 5833-02, group A provides higher values in both interactions for cement setting time. Formulation with $1 \mathrm{~h}$ of sonication time, $2.0 \mathrm{wt}$. \% of BPO and $0.5 \mathrm{wt} . \%$ of GO presented the highest setting time.

Table 3. Grouping information for $t_{\text {set }}$ using Tukey's test and $95 \%$ confidence.

\begin{tabular}{|c|c|c|c|c|c|c|c|c|}
\hline $\begin{array}{c}\text { Sonication Time } \\
* \text { BPO/Solid Ratio }\end{array}$ & $\begin{array}{l}\text { Mean } \\
\text { (s) }\end{array}$ & Grouping * & $\begin{array}{l}\text { Sonication Time } \\
\text { * GO/Liquid ratio }\end{array}$ & $\begin{array}{l}\text { Mean } \\
\text { (s) }\end{array}$ & \multicolumn{4}{|c|}{ Grouping * } \\
\hline $1-2.0$ & 413 & A & $1-0.5$ & 482 & $\mathrm{~A}$ & & & \\
\hline $1-2.5$ & 393 & B & $5-0.5$ & 460 & A & & & \\
\hline $5-2.0$ & 292 & B & $5-0.3$ & 425 & B & & & \\
\hline \multirow[t]{7}{*}{$5-2.5$} & 386 & B & $1-0.3$ & 420 & B & & & \\
\hline & & & $1-0.2$ & 400 & B & $\mathrm{C}$ & & \\
\hline & & & $1-0.1$ & 377 & & $\mathrm{C}$ & D & \\
\hline & & & $5-0.2$ & 372 & & & $\mathrm{D}$ & \\
\hline & & & $5-0.1$ & 355 & & & $\mathrm{D}$ & $\mathrm{E}$ \\
\hline & & & $1-0.0$ & 336 & & & & $\mathrm{E}$ \\
\hline & & & $5-0.0$ & 333 & & & & $\mathrm{E}$ \\
\hline
\end{tabular}

* Means that do not share a letter are significantly different.

\subsection{Mechanical Properties}

\subsubsection{Compressive Properties}

The models proposed for the variables compressive strength and compressive modulus met the assumption of normality on errors with significance levels greater than $10 \%$. The variance analysis presented in Table S3 showed that in both properties, the sum of squares (SS) of the effects studied is greater than the sum of squares of the errors, evidenced by $\mathrm{R}^{2}$ values of $96.26 \%$ and $96.6 \%$ for the strength and modulus, respectively. These results indicate a more outstanding contribution from the controlled effects (studied factors) than the random effects (they are random variables, and they are all those effects that could not be controlled or are not controllable and will go into error).

- Compressive strength

Figure 6 shows that the compressive strength is maximum when the sonication time is $5 \mathrm{~h}$ with $\mathrm{BPO} /$ solid ratio of $2.0 \%$ and $\mathrm{GO} /$ liquid ratio of $0.3 \%$, and decreases when sonication time drops to $1 \mathrm{~h}, \mathrm{BPO} /$ solid ratio increases to $2.5 \%$ and GO/liquid ratio is $0.5 \%$ in the formulation. All the formulations studied presented compression strength values higher than the minimum established in ISO 5833-02 of $70 \mathrm{MPa}$ [51]. The decrease in the compressive strength with the increase in the $\mathrm{BPO}$ content can be related to the fact that the higher amount of free radicals generated by BPO during the polymerization reaction activates more monomers that act as nucleation sites for the growth of the polymer chain, 
causing lower molecular weights that directly influence the mechanical behavior of the cement [5].

\section{Interaction Plot for Compressive Strength Data Means (MPa)}

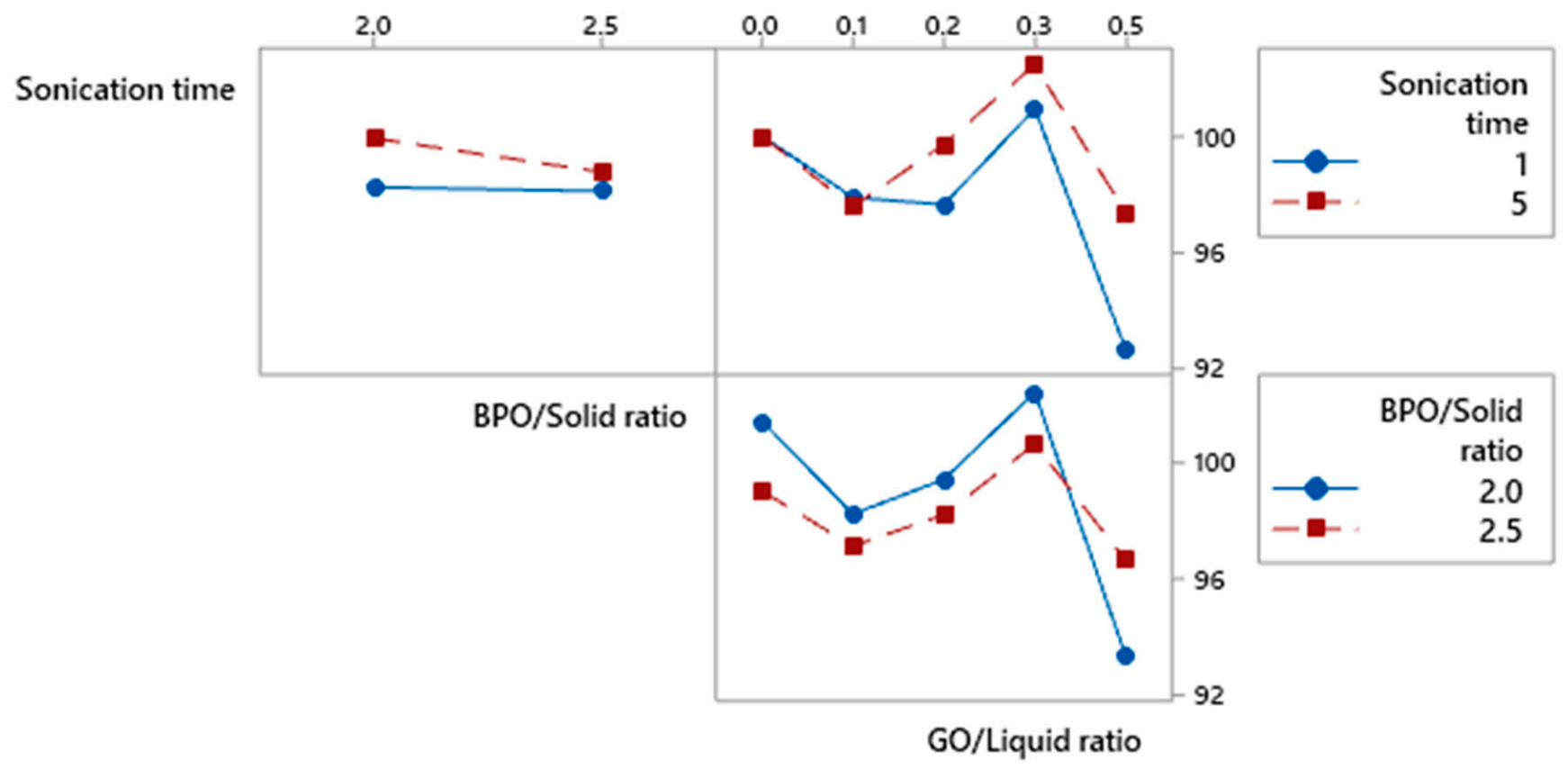

Figure 6. Interaction plot between the effect sonication time, GO/liquid ratio, and $\mathrm{BPO} /$ solid ratio for the variable compressive strength.

Some researchers reported an association between the sonication time, the degree of dispersion, and the thickness of the GO particle [44]. Therefore, the degree of mechanical reinforcement is generated in the matrix [62]. This higher dispersion in the matrix favored the compression strength of the studied ABCs [38]. The presence of GO provides a high surface area [63] that tends and increases the chemical interaction between the $\mathrm{OH}$ groups of $\mathrm{GO}$ and $\mathrm{OCH}_{3}$ and oxygenated groups of PMMA, improving the interfacial adhesion and the strength of the cements $[36,64]$. On the other hand, GO contents above 0.3 wt. $\%$ aggregate and decrease the mechanical properties of the cement [3,37]. Because the transfer of mechanical forces in arthroplasty is achieved through the cement interface, it is necessary to provide good mechanical performance in the cement [63].

The results obtained for verifying the hypothesis tests on the interactions and main effects (Table S3) indicate that in the strength and the compressive modulus, the third and second-order interactions were significant at levels significantly lower than 0.007 ( $p$-value). The analysis of the multiple comparison tests (Tukey's test) is presented in Table 4.

Table 4 shows the comparisons between all treatments for compressive strength. Each of the six treatments of group A has the same statistical effect on the compressive strength, and all of them presented values higher than $100 \mathrm{MPa}$. The treatments are statistically equal within each group B, C, D, E, F, and G. It is essential to highlight that the formulations with 0.3 wt.\% of GO predominated in group A, indicating that this percentage of GO in the formulation could optimize the compressive strength. 
Table 4. Grouping information for compressive strength using Tukey's test and 95\% confidence.

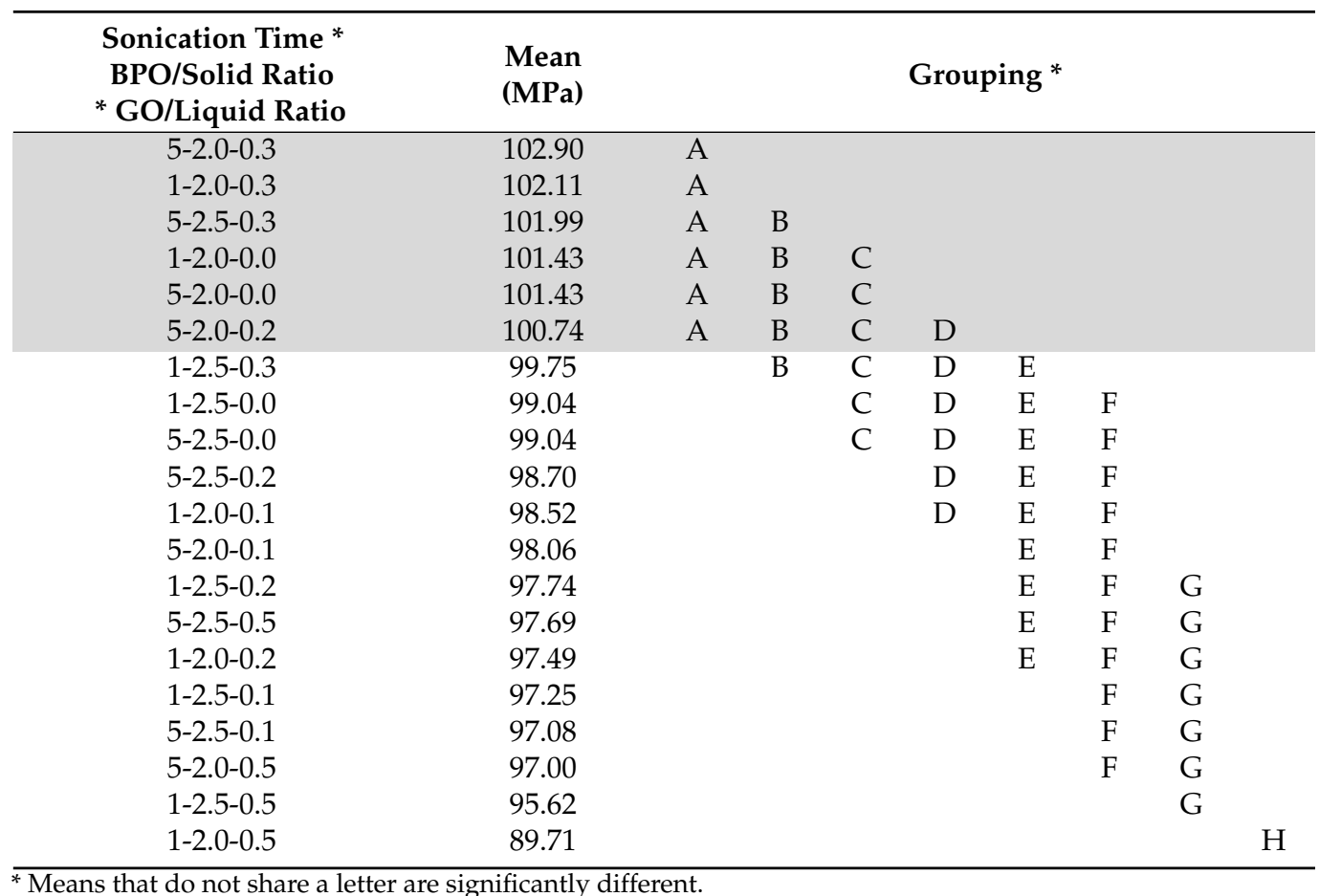

- Compressive modulus

According to Figure 7, shorter sonication time and higher BPO and GO content increase the compression modulus in the solid and liquid phase. ISO 5833-02 does not establish a reference value for this property; however, since the cement is responsible for transferring the mechanical loads between the implant and the bone [1], the compressive type arthroplasty [7] is necessary to understand how this property performs.

\section{Interaction Plot for Compressive Modulus Data Means (MPa)}

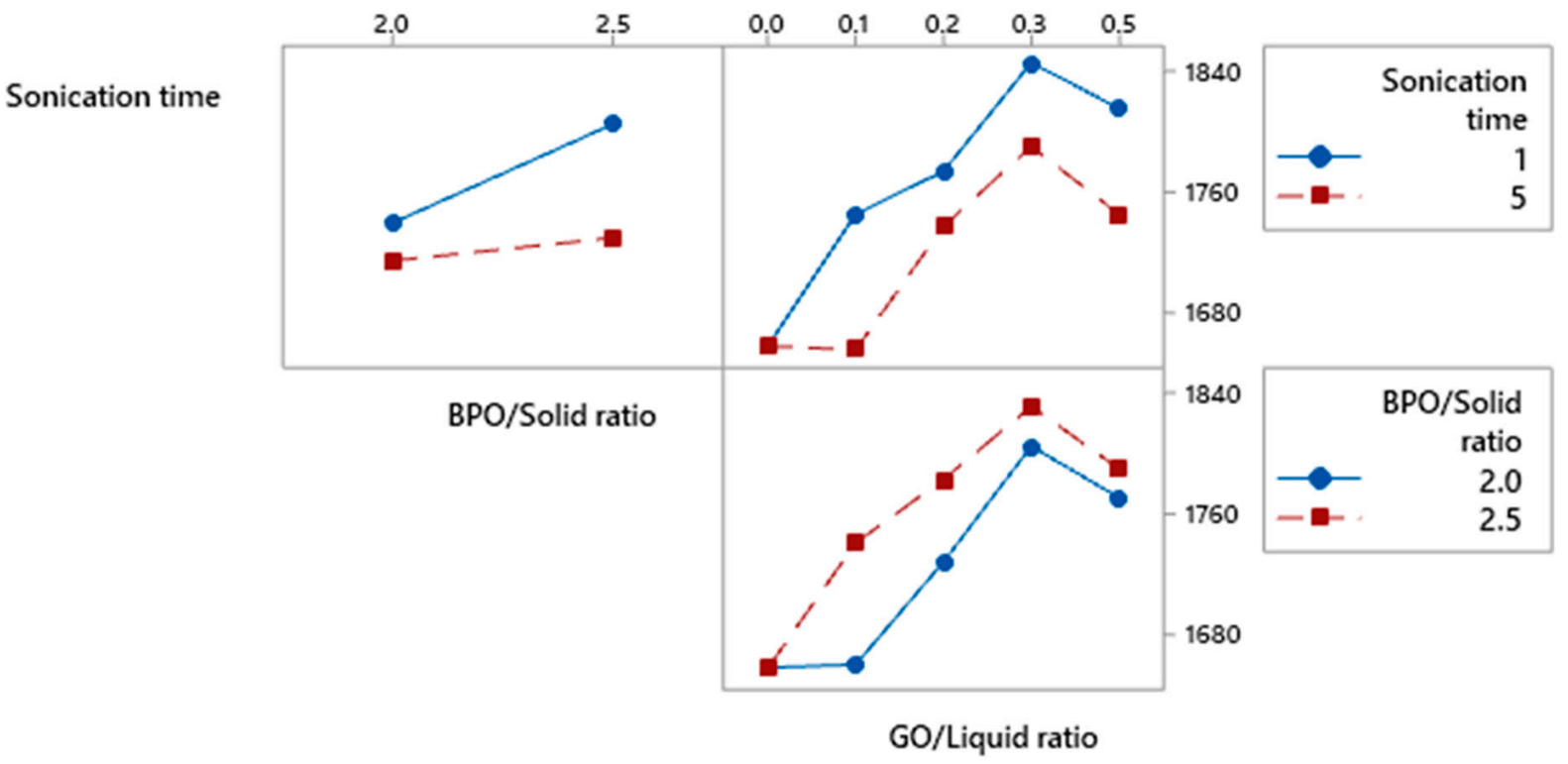

Figure 7. Interaction plot between the effect sonication time, GO/liquid ratio, and $\mathrm{BPO} /$ solid ratio for the variable compressive modulus. 
Larger particles (shorter sonication time) and the higher quantity of polymer chains (higher BPO content) generated a physical impediment for the chains' movement, which increased the stiffness of the ABCs. As in the compressive strength, the GO content increased the compression modulus of the cement. This mechanical reinforcement of GO over ABCs formulations has been reported by several authors [36-65]. It is possible to establish that the formulations with $1 \mathrm{~h}$ of sonication time, $2.5 \mathrm{wt}$. $\%$ of BPO, and 0.3 or $0.5 \mathrm{wt}$ \% maximize the compression module and present an equal effect on this property (Table 5). The module's lowest values are reached with the lowest GO percentages (Groups $\mathrm{H}$ and I).

Table 5. Grouping information for compressive modulus using Tukey's test and 95\% confidence.

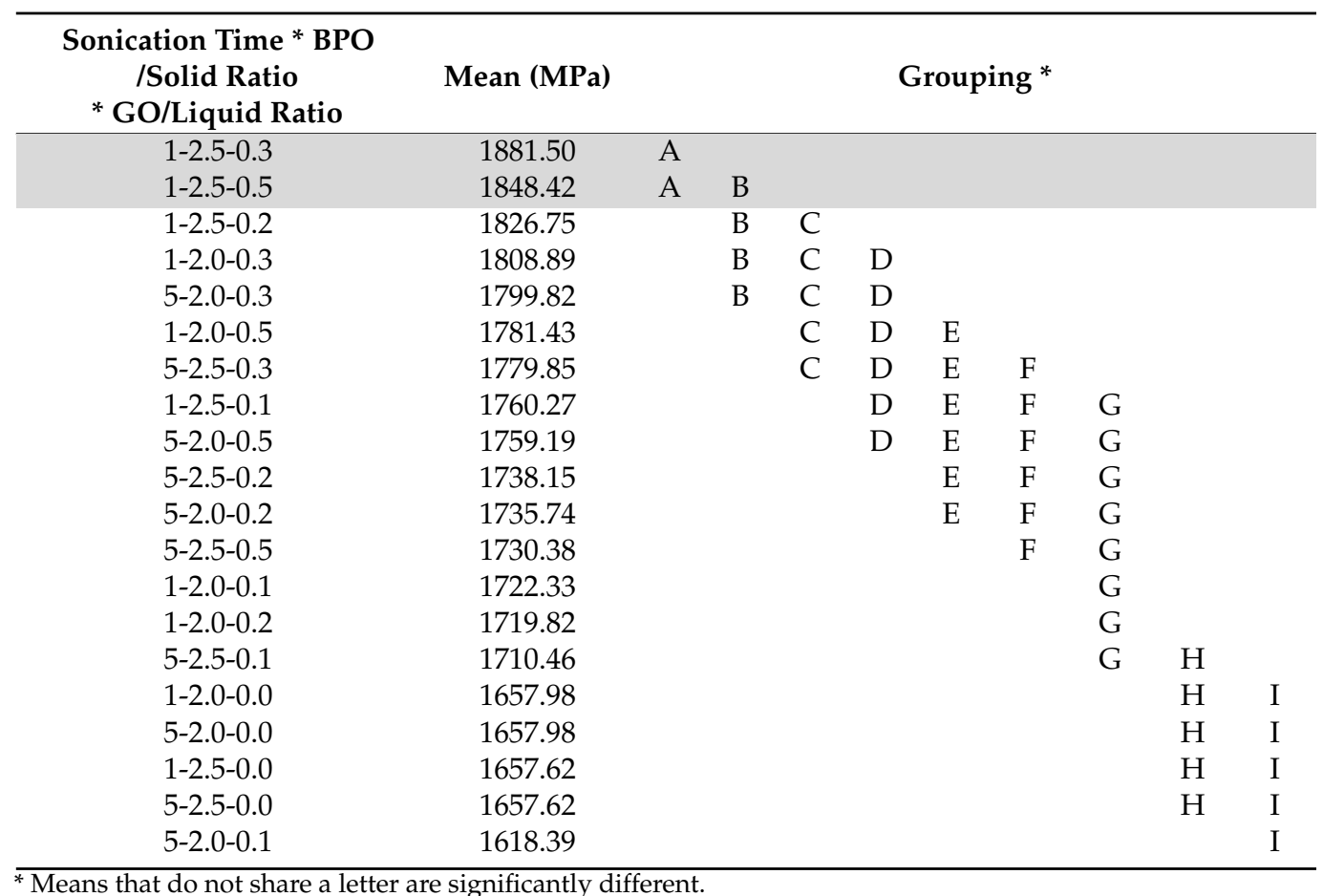

Although the behavior reported for the compressive modulus of the cements added with GO is similar to that reported by Pahlevanzadeh et al. [63] with the use of reduced graphene oxide (rGO), it is noted that the values obtained with GO are higher, possibly due to the greater ease of chemical interaction of the functional groups of GO, which are found in lower proportion in rGO.

\subsubsection{Bending Properties}

To model the effect of the sonication time, $\mathrm{BPO} /$ solid ratio, and GO/liquid ratio, a completely randomized design model with a factorial structure was proposed, which meets the assumptions of normality about error of the model, at significance levels more significant than the $p$-value $=0.15$. Through the analysis of variance, the hypotheses about the interaction between effects are tested (Table S4), showing that effects interaction (Sonication time * GO/Solid ratio; BPO/Solid ratio * GO/Liquid ratio) were significant at levels below 0.001 in the proposed model. For both bending strength and bending modulus, with these models, determination coefficients of $93.47 \%$ and $92.13 \%$, respectively, were obtained, which are a good measure of the controlled effects' contribution to the total variation.

- $\quad$ Bending strength

The increase in sonication time and GO content increases ABCs' bending strength, as shown in Figure 8. In contrast, the rise in BPO content decreases this property. ISO 
5833-02 [51] establishes a minimum bending strength of $50 \mathrm{MPa}$, so formulations without $\mathrm{GO}$ and the highest GO content studied do not achieve this requirement.

\section{Interaction Plot for Bending Strength Data Means (MPa)}

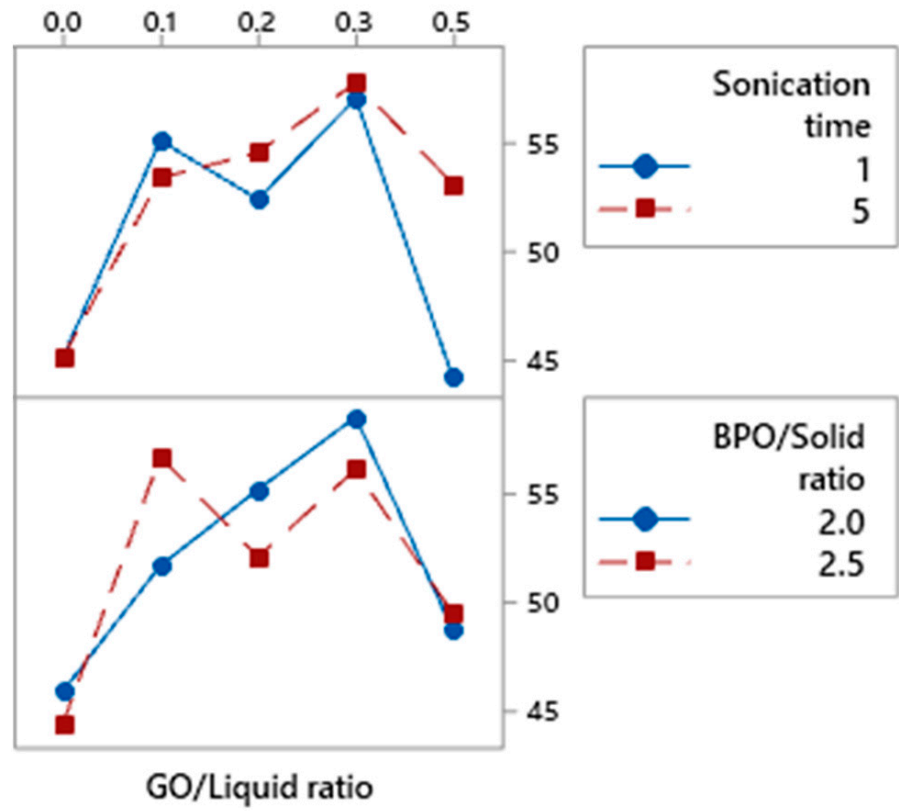

Figure 8. Interaction plot between the effect sonication time vs. GO/liquid ratio and $\mathrm{BPO} /$ solid ratio vs. GO/liquid ratio for the variable bending strength.

As mentioned earlier, for the compressive strength, a higher BPO content has an essential influence on the molecular weight and polymerization degree of PMMA [12] and, therefore, lower cement's mechanical performance. The size reduction generated by the longer sonication time generated a higher mechanical reinforcement [49] and a GO content of $0.3 \mathrm{wt}$. \% produced the highest bending strengths, which coincides with the one reported by Paz et al. [3] and by our group in other investigations [37,38].

Tukey's post-ANOVA test for the variable bending strength shown in Table 6 indicates that the formulations that maximize bending strength are those with GO contents between 0.1 and $0.3 \mathrm{wt} . \%$. There are no significant differences in the bending strength value of the formulations to which the same letter is assigned so that all formulations grouped as A generate the highest possible values in this property and are above the minimum requirement in ISO 5833-02 [51].

Table 6. Grouping information for bending strength using Tukey's test and 95\% confidence.

\begin{tabular}{|c|c|c|c|c|c|c|c|c|c|c|c|}
\hline Sonication Time * & Mean & & Gro & ng * & & BPO/Solid Ratio & Mean & \multicolumn{4}{|c|}{ Grouping * } \\
\hline $3-0.3$ & 31.74 & A & & & & $2.0-0.3$ & 30.30 & & & & \\
\hline $1-0.3$ & 57.01 & A & B & & & $2.5-0.1$ & 56.75 & A & & & \\
\hline $1-0.1$ & 55.10 & A & B & C & & $2.5-0.3$ & 56.17 & A & & & \\
\hline $5-0.2$ & 54.54 & A & B & $\mathrm{C}$ & & $2.0-0.2$ & 55.11 & A & B & & \\
\hline $5-0.1$ & 53.38 & $\mathrm{~A}$ & B & $\mathrm{C}$ & & $2.5-0.2$ & 51.84 & & B & C & \\
\hline $5-0.5$ & 53.06 & & B & $\mathrm{C}$ & & $2.0-0.1$ & 51.72 & & B & C & \\
\hline $1-0.2$ & 52.41 & & & $\mathrm{C}$ & & $2.0-0.5$ & 48.67 & & & C & D \\
\hline $1-0.0$ & 45.14 & & & & $\mathrm{D}$ & $2.5-0.5$ & 48.56 & & & $\mathrm{C}$ & $\mathrm{D}$ \\
\hline $5-0.0$ & 45.14 & & & & $\mathrm{D}$ & $2.0-0.0$ & 45.91 & & & & $\mathrm{D}$ \\
\hline $1-0.5$ & 44.17 & & & & $\mathrm{D}$ & $2.5-0.0$ & 44.37 & & & & $\mathrm{D}$ \\
\hline
\end{tabular}

${ }^{*}$ Means that do not share a letter are significantly different. 
On the other hand, the addition of $0.5 \mathrm{wt} . \%$ of GO does not benefit the ABC from the bending strength perspective. The results of Tukey's test show that the addition of the maximum GO content statistically has the same effect on this property as the basic formulation without the addition of GO (Group D in both interactions) and that both GO contents are below the minimum strength required in the standard (50 MPa).

- $\quad$ Bending modulus

According to Figures 7 and 9, the bending modulus and the compression modulus increase with higher BPO content, shorter sonication time, and higher GO content up to 0.3 wt. $\%$. The higher the polymer chains during polymerization, the larger particle size, and GO nanoparticles' presence increases the ABCs' stiffness [66]. Other researchers found a similar modulus behavior concerning the BPO content in ABCs formulations [1,57]. In addition, it has been reported the increase in the mechanical properties of ABCs $[3,35,67]$ and other types of polymeric materials with the addition of GO thanks to the presence of hydroxyl, carboxylic, and epoxy groups on their surface and is consequently more accessible to disperse $[47,68,69]$.

\section{Interaction Plot for Bending Modulus Data Means}

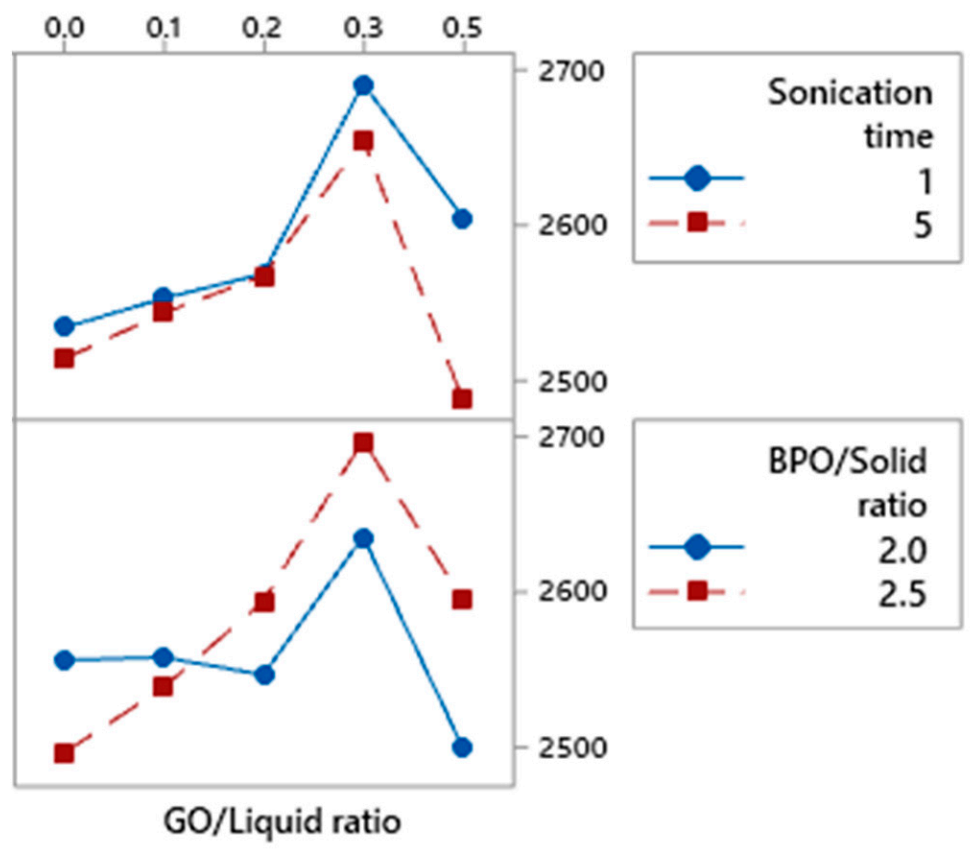

Figure 9. Interaction plot between the effect sonication time vs. GO/liquid ratio and $\mathrm{BPO} /$ solid ratio vs. GO/liquid ratio for the Bending variable modulus.

Concerning the sonication time, Ormsy et al. [70] reported an improvement in the cement mechanical properties by mixing multilayer carbon nanotubes in the liquid phase with ultrasound due to the homogenization and dispersion of the nanotubes in the liquid phase.

According to ISO, the bending modulus of all formulations was between 2.4 and 2.7 GPa (Table 7), which means that all formulations studied present bending modulus values above $1800 \mathrm{MPa}$, which is the minimum required for ABCs 5833-02 [51]. The formulations with $0.3 \mathrm{wt} \%$ of GO, 1 or $5 \mathrm{~h}$ of sonication, and $2.5 \mathrm{wt}$. $\%$ of BPO presented the highest values in this property, represented in higher stiffness of the cements. 
Table 7. Grouping information for the bending modulus using Tukey's test and 95\% confidence.

\begin{tabular}{|c|c|c|c|c|c|c|c|c|c|c|c|c|}
\hline $\begin{array}{l}\text { Sonication Time } \\
\text { * GO/Liquid Ratio }\end{array}$ & $\begin{array}{l}\text { Mean } \\
(\mathrm{MPa})\end{array}$ & \multicolumn{5}{|c|}{ Grouping * } & $\begin{array}{l}\text { BPO/Solid Ratio } \\
\text { * GO/Liquid Ratio }\end{array}$ & $\begin{array}{l}\text { Mean } \\
\text { (MPa) }\end{array}$ & \multicolumn{4}{|c|}{ Grouping * } \\
\hline $1-0.3$ & 2690.23 & A & & & & & $2.5-0.3$ & 2706.26 & A & & & \\
\hline $5-0.3$ & 2651.86 & A & B & & & & $2.0-0.3$ & 2635.83 & & B & & \\
\hline $1-0.5$ & 2595.33 & & B & C & & & $2.5-0.2$ & 2594.27 & & B & C & \\
\hline $5-0.2$ & 2574.34 & & & $\mathrm{C}$ & $\mathrm{D}$ & & $2.5-0.5$ & 2583.08 & & B & $\mathrm{C}$ & \\
\hline $1-0.2$ & 2568.70 & & & $\mathrm{C}$ & $\mathrm{D}$ & & $2.0-0.1$ & 2558.13 & & & C & D \\
\hline $1-0.1$ & 2552.97 & & & $\mathrm{C}$ & $\mathrm{D}$ & & $2.0-0.0$ & 2556.24 & & & C & D \\
\hline $5-0.1$ & 2543.64 & & & $\mathrm{C}$ & $\mathrm{D}$ & E & $2.0-0.2$ & 2548.78 & & & C & $\mathrm{D}$ \\
\hline $1-0.0$ & 2534.07 & & & $\mathrm{C}$ & $\mathrm{D}$ & E & $2.5-0.1$ & 2538.47 & & & $\mathrm{C}$ & $\mathrm{D}$ \\
\hline $5-0.0$ & 2521.01 & & & & $\mathrm{D}$ & E & $2.0-0.5$ & 2499.69 & & & & D \\
\hline $5-0.5$ & 2487.44 & & & & & E & $2.5-0.0$ & 2498.84 & & & & $\mathrm{D}$ \\
\hline
\end{tabular}

${ }^{*}$ Means that do not share a letter are significantly different.

In the $\mathrm{ABC}$ s formulations, it is necessary to comply with the mechanical and setting properties described in ISO 5833-02 [51] to guarantee the implant's long-term stability [11]. Considering that most of the formulations studied met all the mechanical and set requirements specified in the standard, a selection criterion based on the bending strength was employed since some formulations did not reach the minimum value required. In an $A B C$, it is desirable low values of $T_{\max }$, moderate $t_{\text {set }}$ to facilitate the application of cement (in applications such as vertebroplasties and kyphoplasties, longer setting times are desirable as it allows the surgeon to inject the cement), and high mechanical performance that allows the adequate transfer of loads during the patient's daily activities.

Table 8 presents a summary of the formulation's properties with better performance in bending strength. Although all the formulations mentioned in this table accomplish the requirements outlined in ISO 5833-02, those with $0.3 \mathrm{wt} . \%$ of GO independent of sonication time and BPO content showed the highest mechanical performance. That allows adequate load transfer during the patient's daily activities [7]. The longest $t_{\text {set }}$ that facilitates cement application and the lowest $T_{\max }$ values decrease the risk of thermal necrosis of the surrounding tissue.

Table 8. Summary of grouping information for $T_{\max }, t_{\text {set }}$, compressive strength, compressive modulus, bending strength, and bending modulus for $\mathrm{ABCs}$ formulations with higher bending strength. For all properties, the letter $A$ represents the highest values and the letter $G$ the lowest.

\begin{tabular}{ccccccc}
\hline $\begin{array}{c}\text { Sonication Time * } \\
\text { BPO /Solid Ratio } \\
\text { GO/Liquid Ratio }\end{array}$ & $\boldsymbol{T}_{\text {max }}$ & $\boldsymbol{t}_{\text {set }}$ & $\begin{array}{c}\text { Compressive } \\
\text { Strength }\end{array}$ & $\begin{array}{c}\text { Compressive } \\
\text { Modulus }\end{array}$ & $\begin{array}{c}\text { Bending } \\
\text { Strength }\end{array}$ & $\begin{array}{c}\text { Bending } \\
\text { Modulus }\end{array}$ \\
\hline $5-2.0-0.3$ & $\mathrm{G}$ & $\mathrm{C}$ & $\mathrm{A}$ & $\mathrm{B}$ & $\mathrm{A}$ & $\mathrm{B}$ \\
$1-2.0-0.3$ & $\mathrm{~F}$ & $\mathrm{~B}$ & $\mathrm{~A}$ & $\mathrm{~B}$ & $\mathrm{~A}$ & $\mathrm{~B}$ \\
$5-2.5-0.3$ & $\mathrm{C}$ & $\mathrm{B}$ & $\mathrm{A}$ & $\mathrm{C}$ & $\mathrm{A}$ & $\mathrm{A}$ \\
$1-2.5-0.3$ & $\mathrm{G}$ & $\mathrm{D}$ & $\mathrm{B}$ & $\mathrm{A}$ & $\mathrm{A}$ & $\mathrm{A}$ \\
$1-2.5-0.1$ & $\mathrm{C}$ & $\mathrm{F}$ & $\mathrm{F}$ & $\mathrm{D}$ & $\mathrm{A}$ & $\mathrm{C}$ \\
$5-2.5-0.1$ & $\mathrm{C}$ & $\mathrm{G}$ & $\mathrm{F}$ & $\mathrm{G}$ & $\mathrm{A}$ & $\mathrm{E}$ \\
$5-2.0-0.2$ & $\mathrm{C}$ & $\mathrm{F}$ & $\mathrm{A}$ & $\mathrm{E}$ & $\mathrm{A}$ & $\mathrm{D}$ \\
$1-2.0-0.2$ & $\mathrm{C}$ & $\mathrm{D}$ & $\mathrm{E}$ & $\mathrm{G}$ & $\mathrm{A}$ & $\mathrm{C}$ \\
$1-2.0-0.1$ & $\mathrm{E}$ & $\mathrm{F}$ & $\mathrm{D}$ & $\mathrm{G}$ & $\mathrm{A}$ & $\mathrm{C}$ \\
\hline
\end{tabular}

${ }^{*}$ Means that do not share a letter are significantly different.

The characteristics mentioned in the formulations with $0.3 \mathrm{wt} . \%$ of GO make them promising to be applied as $\mathrm{ABCs}$; therefore, complementary studies of properties such as residual monomer content, cell viability, antiviral activity, among others, are suggested to evaluate how these properties are affected by the BPO content and the sonication time of GO nanoparticles, to limit these factors. 


\section{Conclusions}

Using a factorial experiment design completely randomized for evaluating the mechanical and setting properties of $\mathrm{ABC}$ allowed the optimization of $\mathrm{BPO} /$ solid ratio, sonication time, and $\mathrm{GO} /$ liquid ratio factors, obtaining a group of formulations that satisfy the requirements proposed in ISO 5833-02.

The increase in the BPO content favored the stiffness of the cement by increasing the compression and bending modulus; however, it increased the $T_{\max }$ and decreased the $t_{\text {set }}$, compression, and bending strength.

The sonication time favored the compressive and bending strength of the ABCs and simultaneously increased $T_{\max }$ when incorporating more effective content of BPO, reducing the $t_{\text {set }}$ and the stiffness of the cement using the reduction of the compressive and bending modulus.

The increase in GO content favored the setting properties, as it decreased $T_{\max }$ and increased $t_{\text {set }}$. Moreover, GO up to $0.3 \mathrm{wt}$. $\%$ had a beneficial effect on the mechanical properties in compression and bending. The addition of $0.5 \mathrm{wt} . \%$ of GO generated a significant decrease in the mechanical properties possibly due to the formation of agglomerates. The formulations with a GO content of $0.3 \mathrm{wt} . \%$ are of interest in the formulations that meet the mechanical and setting requirements since they presented higher mechanical performance, longer $t_{\text {set }}$, and the lowest $T_{\max }$ values.

Supplementary Materials: The following are available online at https:/ /www.mdpi.com/article/10 .3390/app11115185/s1, Table S1: Completely random factorial design, Table S2: Analysis of variance of the variables Maximum temperature (Tmax), and Setting time (tset), Table S3: Analysis of variance of the variable Compressive strength, and Compressive modulus and Table S4: Analysis of variance of the variables Bending strength and Bending modulus.

Author Contributions: Conceptualization, L.M.R.R., M.E.V.Z., J.H.M.H., and C.D.G.-T.; methodology, L.M.R.R., and M.E.V.Z.; software, M.G.S., and M.E.V.Z.; formal analysis, L.M.R.R., M.E.V.Z. and M.G.S.; investigation, L.M.R.R., and M.E.V.Z.; resources, J.H.M.H., and C.D.G.-T. and R.A.; writingoriginal draft preparation, L.M.R.R., M.E.V.Z., and M.G.S.; writing-review and editing, M.E.V.Z., C.D.G.-T., and R.A.; supervision, J.H.M.H., and C.D.G.-T.; project administration, J.H.M.H.; funding acquisition, J.H.M.H., and R.A. All authors have read and agreed to the published version of the manuscript.

Funding: This research was funded by Sistema General de Regalías-FCTeI-Colombia (BPIN: 2013000100300).

Institutional Review Board Statement: Not applicable.

Informed Consent Statement: Not applicable.

Data Availability Statement: The data presented in this study are available on request from the corresponding author.

Acknowledgments: Author Mayra Eliana Valencia Zapata thanks MinCiencias for funding her doctoral studies.

Conflicts of Interest: The authors declare no conflict of interest.

\section{References}

1. Hasenwinkel, J.M.; Lautenschlager, E.P.; Wixson, R.L.; Gilbert, J.L. A novel high-viscosity, two-solution acrylic bone cement: Effect of chemical composition on properties. J. Biomed. Mater. Res. 1999, 47, 36-45. [CrossRef]

2. Brauer, G.M.; Steinberger, D.R.; Stansbury, J.W. Dependence of curing time, peak temperature, and mechanical properties on the composition of bone cement. J. Biomed. Mater. Res. 1986, 20, 839-852. [CrossRef] [PubMed]

3. Paz, E.; Forriol, F.; del Real, J.C.; Dunne, N. Graphene oxide versus graphene for optimisation of PMMA bone cement for orthopaedic applications. Mater. Sci. Eng. C 2017, 77, 1003-1011. [CrossRef] [PubMed]

4. Rusu, M.C.; Ichim, I.C.; Popa, M.; Rusu, M. New radiopaque acrylic bone cement. II. Acrylic bone cement with bromine-containing monomer. J. Mater. Sci. Mater. Med. 2008, 19, 2609-2617. [CrossRef] [PubMed]

5. Nussbaum, D.A.; Gailloud, P.; Murphy, K. The Chemistry of Acrylic Bone Cements and Implications for Clinical Use in Image-guided Therapy. J. Vasc. Interv. Radiol. 2004, 15, 121-126. [CrossRef] [PubMed] 
6. Madigan, S.; Towler, M.R.; Lewis, G. Influence of two changes in the composition of an acrylic bone cement on some of its properties: The case of Surgical Simplex ${ }^{\circledR}$ P. J. Mater. Sci. 2006, 41, 5758-5759. [CrossRef]

7. Madigan, S.; Towler, M.R.; Lewis, G. Optimisation of the composition of an acrylic bone cement: Application to relative amounts of the initiator and the activator/co-initiator in Surgical Simplex ${ }^{\circledR}$ P. J. Mater. Sci. Mater. Med. 2006, 17, 307-311. [CrossRef] [PubMed]

8. Sharma, R.; Kapusetti, G.; Bhong, S.Y.; Roy, P.; Singh, S.K.; Singh, S.; Balavigneswaran, C.K.; Mahato, K.K.; Ray, B.; Maiti, P.; et al. Osteoconductive Amine-Functionalized Graphene-Poly(methyl methacrylate) Bone Cement Composite with Controlled Exothermic Polymerization. Bioconjug. Chem. 2017, 28, 2254-2265. [CrossRef] [PubMed]

9. Kuehn, K.-D.; Ege, W.; Gopp, U. Acrylic bone cements: Composition and properties. Orthop. Clin. N. Am. 2005, 36, 17-28. [CrossRef] [PubMed]

10. IMAI, Y.; OHYAMA, A. Characterization of Powder Components of Commercial Bone Cements. Dent. Mater. J. 2001, 20, 345-352. [CrossRef]

11. Kühn, K.-D. Bone Cements; Springer: Berlin, Germany, 2000; ISBN 9783642641152.

12. Yang, D.H.; Yoon, G.H.; Kim, S.H.; Rhee, J.M.; Kim, Y.S.; Khang, G. Surface and chemical properties of surface-modified UHMWPE powder and mechanical and thermal properties of it impregnated PMMA bone cement, III: Effect of various ratios of initiator/inhibitor on the surface modification of UHMWPE powder. J. Biomater. Sci. Polym. Ed. 2005, 16, 1121-1138. [CrossRef] [PubMed]

13. Dunne, N.; Ormsby, R.; Mitchell, C. Carbon Nanotubes in Acrylic Bone Cement; Springer Series in Biomaterials Science and Engineering; Antoniac, I., Wang, M., Eds.; Springer: New York, NY, USA, 2013; pp. 173-200. ISBN 9781461443278.

14. Dalby, M.J.; Di Silvio, L.; Harper, E.J.; Bonfield, W. In vitro evaluation of a new polymethylmethacrylate cement reinforced with hydroxyapatite. J. Mater. Sci. Mater. Med. 1999, 10, 793-796. [CrossRef] [PubMed]

15. Espigares, I.; Elvira, C.; Mano, J.F.; Vázquez, B.; San Román, J.; Reis, R.L. New partially degradable and bioactive acrylic bone cements based on starch blends and ceramic fillers. Biomaterials 2002, 23, 1883-1895. [CrossRef]

16. Lozano, K.; Mina, J.; Zuluaga, F.; Valencia, C.; Valencia, M. Influencia de la incorporación de un co-monómero alcalino e hidroxiapatita en las propiedades de cementos óseos acrílicos. DYNA 2013, 80, 153-162.

17. Heikkilä, J.T.; Aho, A.J.; Kangasniemi, I.; Yli-Urpo, A. Polymethylmethacrylate composites: Disturbed bone formation at the surface of bioactive glass and hydroxyapatite. Biomaterials 1996, 17, 1755-1760. [CrossRef]

18. Fernández, M.; Méndez, J.A.; Vázquez, B.; San Román, J.; Ginebra, M.P.; Gil, F.J.; Manero, J.M.; Planell, J.A. Acrylic-phosphate glasses composites as self-curing controlled delivery systems of antibiotics. J. Mater. Sci. Mater. Med. 2002, 13, $1251-1257$. [CrossRef]

19. Lopes, P.P.; Leite Ferreira, B.J.M.; Almeida, N.A.F.; Fredel, M.C.; Fernandes, M.H.V.; Correia, R.N. Preparation and study of in vitro bioactivity of PMMA-co-EHA composites filled with a $\mathrm{Ca}_{3}\left(\mathrm{PO}_{4}\right)_{2}-\mathrm{SiO}_{2}-\mathrm{MgO}$ glass. Mater. Sci. Eng. C 2008, 28, 572-577. [CrossRef]

20. Lopes, P.P.; Leite Ferreira, B.J.M.; Gomes, P.S.; Correia, R.N.; Fernandes, M.H.; Fernandes, M.H.V. Silicate and borate glasses as composite fillers: A bioactivity and biocompatibility study. J. Mater. Sci. Mater. Med. 2011, 22, 1501-1510. [CrossRef]

21. Lopes, P.P.; Garcia, M.P.; Fernandes, M.H.; Fernandes, M.H.V. Acrylic formulations containing bioactive and biodegradable fillers to be used as bone cements: Properties and biocompatibility assessment. Mater. Sci. Eng. C 2013, 33, 1289-1299. [CrossRef]

22. Fini, M.; Giavaresi, G.; Nicoli Aldini, N.; Torricelli, P.; Botter, R.; Beruto, D.; Giardino, R. A bone substitute composed of polymethylmethacrylate and tricalcium phosphate: Results in terms of osteoblast function and bone tissue formation. Biomaterials 2002, 23, 4523-4531. [CrossRef]

23. Shinzato, S.; Nakamura, T.; Kokubo, T.; Kitamura, Y. A new bioactive bone cement: Effect of glass bead filler content on mechanical and biological properties. J. Biomed. Mater. Res. 2001, 54, 491-500. [CrossRef]

24. García-Enriquez, S.; Guadarrama, H.E.R.; Reyes-González, I.; Mendizábal, E.; Jasso-Gastinel, C.F.; García-Enriquez, B.; RembaoBojórquez, D.; Pane-Pianese, C. Mechanical performance and in vivo tests of an acrylic bone cement filled with bioactive sepia officinalis cuttlebone. J. Biomater. Sci. Polym. Ed. 2010, 21, 113-125. [CrossRef] [PubMed]

25. Wekwejt, M.; Michalska-Sionkowska, M.; Bartmański, M.; Nadolska, M.; Łukowicz, K.; Pałubicka, A.; Osyczka, A.M.; Zieliński, A. Influence of several biodegradable components added to pure and nanosilver-doped PMMA bone cements on its biological and mechanical properties. Mater. Sci. Eng. C 2020, 117, 111286. [CrossRef] [PubMed]

26. Zapata, M.E.V.; Tovar, C.D.G.; Hernandez, J.H.M. The role of chitosan and graphene oxide in bioactive and antibacterial properties of acrylic bone cements. Biomolecules 2020, 10, 1616. [CrossRef]

27. Soleymani Eil Bakhtiari, S.; Bakhsheshi-Rad, H.R.; Karbasi, S.; Tavakoli, M.; Razzaghi, M.; Ismail, A.F.; RamaKrishna, S.; Berto, F. Polymethyl Methacrylate-Based Bone Cements Containing Carbon Nanotubes and Graphene Oxide: An Overview of Physical, Mechanical, and Biological Properties. Polymers 2020, 12, 1469. [CrossRef]

28. Mukherjee, S.P.; Gliga, A.R.; Lazzaretto, B.; Brandner, B.; Fielden, M.; Vogt, C.; Newman, L.; Rodrigues, A.F.; Shao, W.; Fournier, P.M.; et al. Graphene oxide is degraded by neutrophils and the degradation products are non-genotoxic. Nanoscale 2018, 10, 1180-1188. [CrossRef]

29. Girish, C.M.; Sasidharan, A.; Gowd, G.S.; Nair, S.; Koyakutty, M. Confocal raman imaging study showing macrophage mediated biodegradation of graphene in vivo. Adv. Healthc. Mater. 2013, 2, 1489-1500. [CrossRef] [PubMed] 
30. Kotchey, G.P.; Allen, B.L.; Vedala, H.; Yanamala, N.; Kapralov, A.A.; Tyurina, Y.Y.; Klein-Seetharaman, J.; Kagan, V.E.; Star, A. The enzymatic oxidation of graphene oxide. ACS Nano 2011, 5, 2098-2108. [CrossRef] [PubMed]

31. Kurapati, R.; Bonachera, F.; Russier, J.; Sureshbabu, A.R.; Ménard-Moyon, C.; Kostarelos, K.; Bianco, A. Covalent chemical functionalization enhances the biodegradation of graphene oxide. 2D Mater. 2018, 5, 015020. [CrossRef]

32. Cacaci, M.; Martini, C.; Guarino, C.; Torelli, R.; Bugli, F.; Sanguinetti, M. Graphene Oxide Coatings as Tools to Prevent Microbial Biofilm Formation on Medical Device. In Advances in Microbiology, Infectious Diseases and Public Health; Donelli, G., Ed.; Springer International Publishing: Cham, Switzerland, 2020; Volume 14, pp. 21-35. ISBN 978-3-030-53647-3.

33. Barui, A.K.; Roy, A.; Das, S.; Bhamidipati, K.; Patra, C.R. Therapeutic Applications of Graphene Oxides in Angiogenesis and Cancers. In Nanoparticles and Their Biomedical Applications; Shukla, A.K., Ed.; Springer: Singapore, 2020; pp. 147-189. ISBN 978-981-15-0391-7.

34. Gonçalves, G.; Cruz, S.M.A.; Ramalho, A.; Grácio, J.; Marques, P.A.A.P. Graphene oxide versus functionalized carbon nanotubes as a reinforcing agent in a PMMA/HA bone cement. Nanoscale 2012, 4, 2937-2945. [CrossRef]

35. Khan, A.A.; Mirza, E.H.; Mohamed, B.A.; Alharthi, N.H.; Abdo, H.S.; Javed, R.; Alhur, R.S.; Vallittu, P.K. Physical, mechanical, chemical and thermal properties of nanoscale graphene oxide-poly methylmethacrylate composites. J. Compos. Mater. 2018, 52, 2803-2813. [CrossRef]

36. Tavakoli, M.; Bakhtiari, S.S.E.; Karbasi, S. Incorporation of chitosan/graphene oxide nanocomposite in to the PMMA bone cement: Physical, mechanical and biological evaluation. Int. J. Biol. Macromol. 2020, 149, 783-793. [CrossRef] [PubMed]

37. Valencia Zapata, M.E.; Ruiz Rojas, L.M.; Mina Hernandez, J.H.; Delgado-Ospina, J.; Grande Tovar, C.D. Acrylic Bone Cements Modified with Graphene Oxide: Mechanical, Physical, and Antibacterial Properties. Polymers 2020, 12, 1773. [CrossRef] [PubMed]

38. Valencia Zapata, M.E.; Mina Hernandez, J.H.; Grande Tovar, C.D.; Valencia Llano, C.H.; Diaz Escobar, J.A.; Vázquez-Lasa, B.; San Román, J.; Rojo, L. Novel Bioactive and Antibacterial Acrylic Bone Cement Nanocomposites Modified with Graphene Oxide and Chitosan. Int. J. Mol. Sci. 2019, 20, 2938. [CrossRef] [PubMed]

39. Gonçalves, G.; Portolés, M.-T.; Ramírez-Santillán, C.; Vallet-Regí, M.; Serro, A.P.; Grácio, J.; Marques, P.A.A.P. Evaluation of the in vitro biocompatibility of PMMA/high-load HA/carbon nanostructures bone cement formulations. J. Mater. Sci. Mater. Med. 2013, 24, 2787-2796. [CrossRef] [PubMed]

40. Mirza, E.H.; Khan, A.A.; Al-Khureif, A.A.; Saadaldin, S.A.; Mohamed, B.A.; Fareedi, F.; Khan, M.M.; Alfayez, M.; Al-Fotawi, R.; Vallittu, P.K.; et al. Characterization of osteogenic cells grown over modified graphene-oxide-biostable polymers. Biomed. Mater. 2019, 14, 65004. [CrossRef] [PubMed]

41. Lee, J.; Jo, J.; Kim, D.; Dev, K.; Kim, H.; Lee, H. Nano-graphene oxide incorporated into PMMA resin to prevent microbial adhesion. Dent. Mater. 2018, 34, e63-e72. [CrossRef] [PubMed]

42. Ye, S.; Feng, J. The effect of sonication treatment of graphene oxide on the mechanical properties of the assembled films. RSC Adv. 2016, 6, 39681-39687. [CrossRef]

43. Nawaz, K.; Ayub, M.; Ul-Haq, N.; Khan, M.B.; Niazi, M.B.K.; Hussain, A. Effects of selected size of graphene nanosheets on the mechanical properties of polyacrylonitrile polymer. Fibers Polym. 2014, 15, 2040-2044. [CrossRef]

44. Vallurupalli, K.; Meng, W.; Liu, J.; Khayat, K.H. Effect of graphene oxide on rheology, hydration and strength development of cement paste. Constr. Build. Mater. 2020, 265, 120311. [CrossRef]

45. Valizadeh, M.; Gholampour, A.; Tran, D.N.H.; Ozbakkaloglu, T.; Losic, D. Physiochemical and mechanical properties of reduced graphene oxide-Cement mortar composites: Effect of reduced graphene oxide particle size. Constr. Build. Mater. 2020, 250, 118832. [CrossRef]

46. Gao, Y.; Picot, O.T.; Bilotti, E.; Peijs, T. Influence of filler size on the properties of poly (lactic acid) (PLA)/graphene nanoplatelet (GNP) nanocomposites. Eur. Polym. J. 2017, 86, 117-131. [CrossRef]

47. Larraza, I.; Ugarte, L.; Fayanas, A.; Gabilondo, N.; Arbelaiz, A.; Corcuera, M.A.; Eceiza, A. Influence of process parameters in graphene oxide obtention on the properties of mechanically strong alginate nanocomposites. Materials 2020, 13, 1081. [CrossRef]

48. Kim, J.; Cote, L.J.; Kim, F.; Yuan, W.; Shull, K.R.; Huang, J. Graphene oxide sheets at interfaces. J. Am. Chem. Soc. 2010, 132, 8180-8186. [CrossRef]

49. Botas, C.; Pérez-Mas, A.M.; Álvarez, P.; Santamaría, R.; Granda, M.; Blanco, C.; Menéndez, R. Optimization of the size and yield of graphene oxide sheets in the exfoliation step. Carbon N. Y. 2013, 63, 576-578. [CrossRef]

50. Skaltsas, T.; Ke, X.; Bittencourt, C.; Tagmatarchis, N. Ultrasonication induces oxygenated species and defects onto exfoliated graphene. J. Phys. Chem. C 2013, 117, 23272-23278. [CrossRef]

51. International Standard ISO 5833: Implants for Surgery. In Acrylic Resin Cements; International Standard: Geneva, Switzerland, 2002; pp. 1-22.

52. Montgomery, D.C. Design and Analysis of Experiments, 10th ed.; John Wiley \& Sons: New York, NY, USA, 2019.

53. Cochran, W.G.; Cox, G.M. Experimental Designs, 2nd ed.; John Wiley \& Sons: New York, NY, USA, 1992.

54. Vazquez, B.; Elvira, C.; Levenfeld, B.; Pascual, B.; Goñi, I.; Gurruchaga, M.; Ginebra, M.P.; Gil, F.X.; Planell, J.A.; Liso, P.A.; et al. Application of tertiary amines with reduced toxicity to the curing process of acrylic bone cements. J. Biomed. Mater. Res. 1997, 34, 129-136. [CrossRef]

55. Vazquez, B.; Deb, S.; Bonfield, W. Optimization of benzoyl peroxide concentration in an experimental bone cement based on poly (methyl methacrylate). J. Mater. Sci. Mater. Med. 1997, 8, 455-460. [CrossRef] [PubMed] 
56. López, A.; Unosson, E.; Engqvist, H.; Persson, C. Direct and interactive effects of three variables on properties of PMMA bone cement for vertebral body augmentation. J. Mater. Sci. Mater. Med. 2011, 22, 1599-1606. [CrossRef] [PubMed]

57. Ginebra, M.B.; Gil, F.X.; Planell, J.A.; Pascual, B.; Goni, I.; Gurruchaga, M.; Levenfeld, B.; Vázouez, B.; Roman, J.S. Relationship between the morphology of PMMA particles and properties of acrylic bone cements. J. Mater. Sci. Mater. Med. 1996, 7, 375-379. [CrossRef]

58. Balandin, A. Thermal Properties of Graphene, Carbon Nanotubes and Nanostructured Carbon Materials. Nat. Mater. 2011, 10, 569-581. [CrossRef] [PubMed]

59. Ormsby, R.W.; Modreanu, M.; Mitchell, C.A.; Dunne, N.J. Carboxyl functionalised MWCNT/polymethyl methacrylate bone cement for orthopaedic applications. J. Biomater. Appl. 2014, 29, 209-221. [CrossRef] [PubMed]

60. Paz, E.; Ballesteros, Y.; Abenojar, J.; del Real, J.C.; Dunne, N.J. Graphene oxide and graphene reinforced PMMA bone cements: Evaluation of thermal properties and biocompatibility. Materials 2019, 12, 3146. [CrossRef] [PubMed]

61. Cai, Y.; Fadil, Y.; Jasinski, F.; Thickett, S.C.; Agarwal, V.; Zetterlund, P.B. Miniemulsion polymerization using graphene oxide as surfactant: In situ grafting of polymers. Carbon N. Y. 2019, 149, 445-451. [CrossRef]

62. Burresi, E.; Taurisano, N.; Protopapa, M.L.; Latterini, L.; Palmisano, M.; Mirenghi, L.; Schioppa, M.; Morandi, V.; Mazzaro, R.; Penza, M. Influence of the synthesis conditions on the microstructural, compositional and morphological properties of graphene oxide sheets. Ceram. Int. 2020, 46, 22067-22078. [CrossRef]

63. Pahlevanzadeh, F.; Bakhsheshi-Rad, H.R.; Kharaziha, M.; Kasiri-Asgarani, M.; Omidi, M.; Razzaghi, M.; Ismail, A.F.; Sharif, S.; RamaKrishna, S.; Berto, F. CNT and rGO reinforced PMMA based bone cement for fixation of load bearing implants: Mechanical property and biological response. J. Mech. Behav. Biomed. Mater. 2021, 116, 104320. [CrossRef] [PubMed]

64. Ormsby, R.; McNally, T.; O’Hare, P.; Burke, G.; Mitchell, C.; Dunne, N. Fatigue and biocompatibility properties of a poly (methyl methacrylate) bone cement with multi-walled carbon nanotubes. Acta Biomater. 2012, 8, 1201-1212. [CrossRef]

65. Pahlevanzadeh, F.; Bakhsheshi-Rad, H.R.; Hamzah, E. In-vitro biocompatibility, bioactivity, and mechanical strength of PMMAPCL polymer containing fluorapatite and graphene oxide bone cements. J. Mech. Behav. Biomed. Mater. 2018, 82, $257-267$. [CrossRef] [PubMed]

66. Wright, Z.M.; Pandit, A.M.; Karpinsky, M.M.; Holt, B.D.; Zovinka, E.P.; Sydlik, S.A. Bioactive, Ion-Releasing PMMA Bone Cement Filled with Functional Graphenic Materials. Adv. Healthc. Mater. 2021, 10, 2001189. [CrossRef]

67. Khan, A.A.; Mirza, E.H.; Mohamed, B.A.; El-Sharawy, M.A.; Hasil Al-Asmari, M.; Abdullah Al-Khureif, A.; Ahmad Dar, M.; Vallittu, P.K. Static and dynamic mechanical properties of graphene oxide-based bone cementing agents. J. Compos. Mater. 2019, 53, 2297-2304. [CrossRef]

68. Ruiz, S.; Tamayo, J.A.; Ospina, J.D.; Navia Porras, D.P.; Valencia Zapata, M.E.; Mina Hernandez, J.H.; Valencia, C.H.; Zuluaga, F.; Grande Tovar, C.D. Antimicrobial Films Based on Nanocomposites of Chitosan/Poly (vinyl alcohol)/Graphene Oxide for Biomedical Applications. Biomolecules 2019, 9, 109. [CrossRef] [PubMed]

69. Unal, S.; Arslan, S.; Gokce, T.; Melek, B.; Karademir, B. Design and characterization of polycaprolactone-gelatin-graphene oxide scaffolds for drug influence on glioblastoma cells. Eur. Polym. J. 2019, 115, 157-165. [CrossRef]

70. Ormsby, R.; McNally, T.; Mitchell, C.; Dunne, N. Incorporation of multiwalled carbon nanotubes to acrylic based bone cements: Effects on mechanical and thermal properties. J. Mech. Behav. Biomed. Mater. 2010, 3, 136-145. [CrossRef] [PubMed] 